\title{
PEMBUATAN ETIL ASETAT DARI HASIL HIDROLISIS, FERMENTASI DAN ESTERIFIKASI KULIT PISANG RAJA (Musa paradisiaca L.)
}

\author{
Sari Liza Azura Nst, Reni Sutri, Iriany \\ Departemen Teknik Kimia, Fakultas Teknik, Universitas Sumatera Utara, \\ Jl. Almamater Kampus USU Medan 20155, Indonesia \\ Email: sarilizaazura@gmail.com
}

\begin{abstract}
Abstrak
Etil asetat adalah cairan jernih, tak berwarna, berbau khas yang biasa digunakan sebagai penambah cita rasa. Kulit pisang mengandung komponen yang bernilai tinggi, seperti karbohidrat, vitamin $\mathrm{C}$, kalsium dan nutrien lainnya. Tujuan dari penelitian ini adalah untuk memanfaatkan kulit pisang raja (Musa paradisiaca $L$.) dalam pembuatan etil asetat. Variasi yang dilakukan dalam percobaan ini adalah perbandingan bahan baku dan air yaitu 1:4; $1: 7$; 1:10 dan suhu hidrolisis $50^{\circ} \mathrm{C}, 60^{\circ} \mathrm{C}, 70^{\circ} \mathrm{C}$. Pada awalnya kulit pisang dikerok, dikeringkan dan dihaluskan untuk membuat tepung kulit pisang. Tepung kulit pisang raja mempunyai kadar karbohidrat 45,21\% (b/b). Tepung kulit pisang ini dihidrolisis dengan air dan katalis asam klorida selama 180 menit. Hasil hidrolisis difermentasi dengan menggunakan ragi instan 'Fermipan' selama 24 jam dan kemudian didistilasi. Hasil distilasi diesterifikasi dengan asam asetat dan katalis asam klorida selama 15 menit pada suhu $60^{\circ} \mathrm{C}$. Pengaruh dari berbagai variabel proses diamati dalam percobaan ini. Pada kondisi terbaik diperoleh yield etil asetat maksimum sebesar 70,377\% pada kondisi perbandingan bahan baku dan air $=1: 10$ dan suhu hidrolisis $50^{\circ} \mathrm{C}$. Hasil yang diperoleh pada penelitian menunjukkan bahwa kulit pisang raja dapat digunakan sebagai bahan baku alternatif yang murah dan mudah didapat dalam memproduksi etil asetat.
\end{abstract}

Kata Kunci : etil asetat, kulit pisang raja, hidrolisis, fermentasi, esterifikasi, ragi instan

\begin{abstract}
Ethyl acetate is a clear liquid, colorless, smelling typical which commonly used as a flavor enhancer. Banana peels contain high valuable components, such as carbohydrates, vitamin $C$, calcium and other nutrients. The purpose of this study was to utilize the 'raja' banana peel waste (Musa paradisiaca L.) in the making of ethyl acetate. Variations in this experiment is comparison of raw materials and water 1: 4; 1: 7; 1:10 and hydrolysis temperature of $50^{\circ} \mathrm{C}$, $60^{\circ} \mathrm{C}, 70^{\circ} \mathrm{C}$. At first banana peel was scraped, dried and mashed to make banana peel powder.The content of carbohydrates in the 'Raja' banana peel powder is $45.21 \%(\mathrm{w} / \mathrm{w})$. Banana peel powder was hydrolyzed into water for 180 minutes using acid hydrocloric acid as catalist. The hydrolysis product was fermented for 24 hours using instant yeast 'Fermipan' and then was distilled. The Distillation product was esterified with acetic acid and hydrochloric acid as catalyst for 15 minutes at $60^{\circ} \mathrm{C}$. The influence of various process variables were observed in this experiment. The maximum ethyl acetate yield was obtained $70.377 \%$ at condition of raw materials and water ratio $=1: 10$ and hydrolysis temperature of $50^{\circ} \mathrm{C}$. The results obtained in this experiment showed that the 'raja' banana peel can be used as an alternative raw material which low cost and easy to obtain to produce ethyl acetate.
\end{abstract}

Keywords: ethyl acetate, raja banana peel, hydrolysis, fermentation, esterification, instant yeast

\section{Pendahuluan}

Pisang merupakan buah yang tumbuh di daerah-daerah di Indonesia. Menurut data Direktorat Jendral Hortikultura produksi pisang pada tahun 2010 adalah sebanyak 5.755.073 ton [9]. Pisang-pisang ini sebagian besar dikonsumsi oleh dalam negeri. Besarnya konsumsi ini menandakan tingginya kebutuhan masyarakat Indonesia akan buah dan serat. Di sisi lain, hal ini menimbulkan dampak baru, yaitu banyaknya kulit pisang. Adapun berat kulit pisang dari berat keseluruhan buah pisang mencapai $30-40 \%$ dari total berat seluruh buah pisang [16]. Kulit pisang mengandung komponen yang bernilai, seperti karbohidrat, vitamin $\mathrm{C}$, kalsium dan nutrien lainnya. Berdasarkan sifat fisik dan kimianya, limbah kulit pisang sangat berpotensi untuk digunakan sebagai sumber karbon dalam pembuatan alkohol [3]. Alkohol ini kemudian dapat diproses lebih lanjut untuk menghasilkan etil asetat.

Etil asetat adalah cairan jernih, tak berwarna, berbau khas yang digunakan sebagai pelarut tinta, perekat dan resin [17]. Jika 
dibandingkan dengan etanol, etil asetat memiliki koefisien distribusi yang lebih tinggi dibanding etanol termasuk kelarutannya dalam gasoline. Selain dari penggunaannya sebagai pelarut, etil asetat dapat berfungsi sebagai bahan aditif untuk meningkatkan bilangan oktan pada bensin serta dapat berguna sebagai bahan baku kimia serba guna [5]. Pembuatan etil asetat biasanya dilakukan dengan esterifikasi [6].

Tujuan dari penelitian ini adalah untuk menghasilkan etil asetat dari dari bahan baku kulit pisang raja melalui proses fermentasi dan dilanjutkan dengan reaksi esterifikasi, serta mengetahui pengaruh rasio bahan baku : air dan suhu hidrolisis terhadap etil asetat yang dihasilkan dari kulit pisang raja.

\section{Teori}

Terdapat berbagai jenis varietas pisang yang jumlahnya mencapai ratusan. Dari sekian banyak jenis pisang, terdapat satu varietas yang masih kurang proses pengolahannya namun persediaannya melimpah, yaitu pisang raja. Pisang raja termasuk jenis pisang buah [7]

Komposisi kulit pisang raja dapat dilihat pada tabel 1 di bawah ini.

\section{Tabel 1. Komposisi Kulit Pisang Raja (per} 100 gram) [7]

\begin{tabular}{|l|c|c|}
\hline $\begin{array}{c}\text { Komponen } \\
\text { Proksimat }\end{array}$ & Nilai & $\begin{array}{c}\text { Konsentrasi } \\
\% \mathrm{~b} / \mathrm{b}\end{array}$ \\
\hline Energi & $\begin{array}{c}116,00 \\
\mathrm{kkal}\end{array}$ & - \\
\hline Air & $67,30 \mathrm{~g}$ & 67,30 \\
\hline Protein & $0,79 \mathrm{~g}$ & 0,79 \\
\hline Total Lemak & $0,18 \mathrm{~g}$ & 0,18 \\
\hline Karbohidrat & $31,15 \mathrm{~g}$ & 31,15 \\
\hline Serat & $2,30 \mathrm{~g}$ & 2,30 \\
\hline Ampas & $0,58 \mathrm{~g}$ & 0,58 \\
\hline
\end{tabular}

Berdasarkan analisis dinding sel (\% berat kering), komposisi kulit pisang secara keseluruhan mengandung 37,52\% hemiselulosa, $12,06 \%$ selulosa dan 7,04\% lignin [2]. Polisakarida seperti selulosa harus diubah terlebih dahulu menjadi glukosa [14].

Hidrolisis adalah suatu proses antara reaktan dengan air agar suatu senyawa pecah atau terurai. Reaksi ini merupakan reaksi orde satu, karena air yang digunakan berlebih, sehingga perubahan air dapat diabaikan [14].

$$
\begin{aligned}
& \underset{\text { karbohidrat }}{\left(\mathrm{C}_{6} \mathrm{H}_{10} \mathrm{O}_{5}\right) \mathrm{n}}+\underset{\mathrm{nH}}{\mathrm{nH}_{2} \mathrm{O}} \rightarrow \underset{\mathrm{n}}{\mathrm{n}\left(\mathrm{C}_{6} \mathrm{H}_{12} \mathrm{O}_{6}\right)[8]} \text { glukosa }
\end{aligned}
$$

Reaksi hidrolisis kulit pisang menjadi glukosa dapat dilihat pada reaksi di atas. Dimana sejumlah karbohidrat akan diuraikan oleh air melalui reaksi hidrolisis menghasilkan sejumlah glukosa.

Proses hidrolisis dipengaruhi oleh beberapa faktor yaitu $\mathrm{pH}$, suhu dan konsentrasi katalis [14].

Salah satu mikroorganisme yang biasa digunakan dalam fermentasi etanol adalah Saccharomyces cerevisiae. Saccharomyces cerevisiae dapat memfermentasi glukosa, sukrosa, galaktosa serta rafinosa. Saccharomyces cerevesiae dapat toleran terhadap alkohol yang cukup tinggi (12-18\% $\mathrm{v} / \mathrm{v})$, tahan terhadap kadar gula yang tinggi dan tetap aktif melakukan fermentasi pada suhu 4$32^{\circ} \mathrm{C}$, mempunyai kecepatan optimum fermentasi pada $\mathrm{pH} 4,48$ [18].

Proses fermentasi merupakan proses biokimia dimana terjadi perubahan-perubahan atau reaksi-reksi kimia dengan pertolongan jasad renik penyebab fermentasi tersebut bersentuhan dengan zat makanan yang sesuai dengan pertumbuhannya. Akibat terjadinya fermentasi sebagian atau seluruhnya akan berubah menjadi alkohol setelah beberapa waktu lamanya [10].

Proses penguraian glukosa menjadi etanol oleh Saccharomyces cerevesiae akan menghasilkan 2 mol etanol dan 2 mol karbon dioksida dari 1 mol glukosa seperti ditunjukkan pada reaksi di bawah ini.

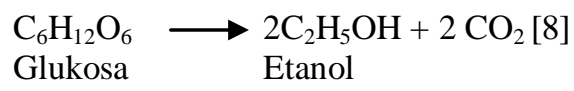

Reaksi asam karboksilat dengan alkohol menghasilkan senyawa ester melalui reaksi yang dikenal dengan nama esterifikasi, dan biasanya menggunakan katalis asam. Reaksi akan berlangsung dengan baik jika direfluks bersama sedikit asam sulfat atau asam klorida [15].

Di indusri dan di laboratorium etil asetat dibuat dengan memanaskan etanol dengan asam asetat glasial dengan penambahan asam sulfat. Reaksi antara asam asetat dan etanol dengan katalis asam sulfat akan menghasilkan etil ester dan air seperti pada reaksi di bawah ini.

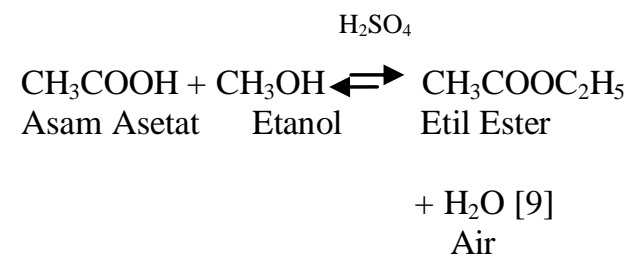


Sifat fisika dan kimia etil asetat dapat dilihat pada tabel 2 berikut.

Tabel 2. Sifat Fisika Etil Asetat [21]

\begin{tabular}{|l|c|}
\hline \multicolumn{1}{|c|}{ Sifat Fisika } & Keterangan \\
\hline Wujud & Cairan Bening \\
\hline Berat Molekul & $88,105 \mathrm{gr} / \mathrm{mol}$ \\
\hline Densitas & $0,897 \mathrm{gr} / \mathrm{ml}$ \\
\hline Titik Leleh & $-83,6^{\circ} \mathrm{C}$ \\
\hline Titik Didih & $77,1^{\circ} \mathrm{C}$ \\
\hline Titik Nyala & $-4^{\circ} \mathrm{C}$ \\
\hline
\end{tabular}

(Data diambil pada keadaan standar $25^{\circ} \mathrm{C}, 100$ Kpa)

\section{Metodologi Penelitian \\ Bahan dan Peralatan}

Bahan yang digunakan adalah kulit pisang raja matang, aquadest, asam klorida, natrium hidroksida, ragi instan 'Fermipan', asam asetat.

Adapun peralatan utama yang digunakan dalam penelitian ini adalah hot plate, magnetic stirrer, refluks kondensor, heating mantle dan peralatan gelas.

\section{Persiapan Bahan Baku}

Kulit pisang dikerok bagian dalamnya, dikeringkan, dihaluskan, diayak dan diperoleh tepung kulit pisang. Kandungan karbohidrat tepung kulit pisang setelah dianalisa dengan metode Luff-Schrool adalah $45,21 \%$.

\section{Hidrolisis Tepung Kulit Pisang Kepok}

Kedalam labu leher satu dimasukkan 50 gram kulit pisang dan air dengan perbandingan bahan baku dan air $=1: 4 ; 1: 7 ; 1: 10(\mathrm{~b} / \mathrm{v})$. Ditambahkan asam klorida $37 \%$ hingga $\mathrm{pH}$ larutan $=1$. Dipanaskan dan diaduk dengan magnetic stirrer selama 180 menit dengan variasi suhu hidrolisis 50,60 , dan $70^{\circ} \mathrm{C}$. Hasil hidrolisis disaring, didinginkan dan dinetralkan dengan larutan $\mathrm{NaOH} \mathrm{0,1} \mathrm{M} \mathrm{hingga} \mathrm{pH}=4,5$. Didapat hidrolisat berupa glukosa yang siap difermentasi.

\section{Fermentasi Hidrolisist}

Hidrolisat disterilisasi pada suhu $105^{\circ} \mathrm{C}$ selama 30 menit. Didinginkan dan ditambahkan ragi instan 'Fermipan' sebanyak 7,14 gram. Dihomogenkan dengan shaker selama 15 menit dengan kecepatan $150 \mathrm{rpm}$. Difermentasi selama 24 jam. Hasil fermentasi kemudian didistilasi. Didapat distilat berupa etanol.

\section{Esterifikasi}

Etanol yang didapat, asam asetat glasial dan katalis asam klorida $37 \%$ dimasukkan ke dalam labu leher tiga dengan perbandingan mol etanol : mol asam asetat $=1: 1$ dan katalis $32 \%$.
Dipanaskan hingga suhu $60^{\circ} \mathrm{C}$ dan dipertahankan selama 15 menit. Didinginkan hingga suhu ruangan. Hasil esterifikasi di ambil untuk dianalisis kadarnya dengan menggunakan gas chromatography.

\section{Pembahasan}

Pengaruh Perbandingan Bahan Baku Dan Air Terhadap Kadar Etil Asetat

Pengaruh perbandingan bahan baku dan air terhadap kadar etil asetat ditunjukkan pada gambar 1 berikut.

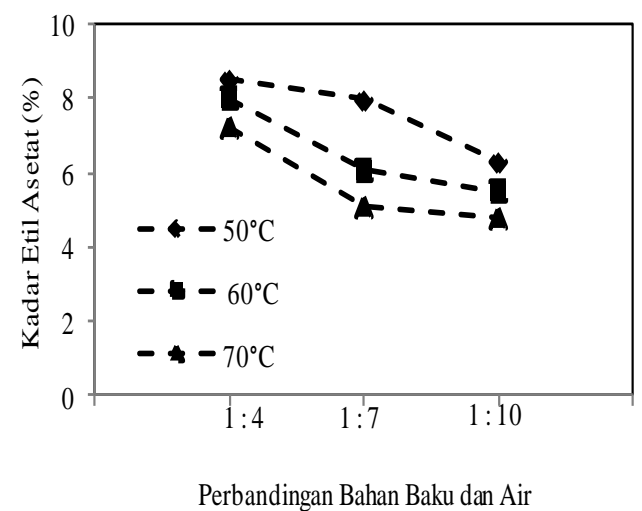

Gambar 1. Pengaruh Perbandingan Bahan Baku dan Air Terhadap Kadar Etil Asetat

Pada gambar 1 dapat dilihat bahwa kadar etil asetat cenderung semakin menurun seiring dengan semakin besarnya rasio perbandingan bahan baku dan air. Pada penelitian ini, kadar etil asetat berkorelasi dengan banyaknya volume distilat dari cairan hasil fermentasi. Semua hasil distilat yang diperoleh dari proses distilasi cairan fermentasi dikonversi menjadi etil asetat melalui proses esterifikasi.

Dari grafik dapat dilihat bahwa kadar etil asetat mengalami kenaikan untuk setiap peningkatan jumlah air. Kadar etil asetat tertinggi yang diperoleh yaitu 8,5206 \% dengan perbandingan bahan baku dan air $=1: 4$ dan suhu $50^{\circ} \mathrm{C}$. Sedangkan kadar etil asetat terendah pada kondisi perbandingan bahan baku dan air 1 : 10 pada suhu $70^{\circ} \mathrm{C}$ yaitu sebesar 4,7666 \%. Hal ini terjadi karena partikel pengotor berupa air ikut menguap pada saat distilasi etanol.

Menurut Owens (2009) untuk setiap rasio campuran etanol dan air, hanya ada satu titik didih yang tepat untuk proses destilasinya. Semakin kecil rasio dari etanol dalam campuran maka titik didih proses akan semakin tinggi. Dan selama proses distilasi berlangsung zat pengotor (air) akan ikut menguap [4].

Oleh karena itu pada kondisi ini volume hasil esterifikasi yang diperoleh menjadi lebih 
tinggi karena banyaknya kandungan air pada distilat etanol tetapi banyaknya volume air ini mengakibatkan kadar etil asetat menjadi rendah. Jadi dapat disimpulkan semakin besar rasio perbandingan bahan baku dan air akan menurunkan kadar dari etil asetat yang diperoleh.

\section{Pengaruh Perbandingan Bahan Baku Dan Air Terhadap Massa Etil Asetat}

Pengaruh perbandingan bahan baku dan air terhadap volume etil asetat ditunjukkan pada gambar 2 berikut.

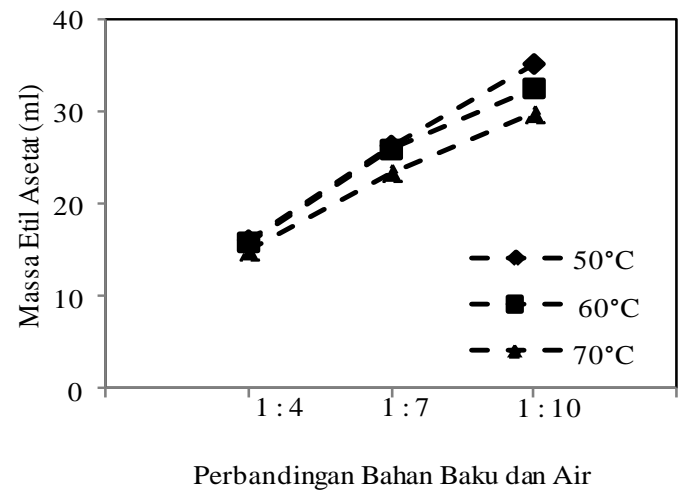

Gambar 2. Pengaruh Perbandingan Bahan Baku dan Air Terhadap Massa Etil Asetat

Pada gambar 2 dapat dilihat bahwa massa etil asetat cenderung meningkat seiring dengan meningkatnya rasio perbandingan bahan baku dan air. Massa etil asetat tertinggi diperoleh pada kondisi perbandingan bahan baku dan air $=1: 10$ dan suhu $50^{\circ} \mathrm{C}$ yaitu 35,189 gram. Dan massa etil asetat terendah diperoleh pada kondisi perbandingan bahan baku dan air $=1$ : 4 dan suhu $70^{\circ} \mathrm{C}$ yaitu 14,961 gram.

Peningkatan jumlah bahan baku yang semakin besar berdampak pada peningkatan konsentrasi hasil hidrolisis. Karena semakin banyak bahan yang bereaksi dengan larutan sehingga dihasilkan hasil yang semakin banyak pula. Akan tetapi jika air yang digunakan sangat berlebihan, tumbukan antara bahan baku dan air akan berkurang sehingga memperlambat jalannya reaksi. Perbandingan antara bahan baku dan air yang tepat akan membuat reaksi hidrolisis berjalan cepat [13, 11, 12]. Dari grafik di atas, semakin meningkatnya rasio perbandingan bahan baku dan air menyebabkan massa etil asetat semakin meningkat, hal ini disebabkan karena seiring peningkatan jumlah air, tumbukan antara bahan baku dan air menjadi lebih baik.

Dari data yang diperoleh dapat diambil kesimpulan bahwa peningkatan jumlah air yang digunakan pada saat hidrolisis dapat menghasilkan glukosa yang lebih banyak, hal ini tentu berpengaruh terhadap massa etil asetat. Hasil penelitian ini sama seperti hasil yang dilaporkan oleh Gusmarwani et al (2010) [19], yang melakukan penelitian dengan menggunakan bonggol pisang dimana hasil penelitian menunjukkan semakin besar perbandingan bahan baku dan air semakin banyak glukosa yang dihasilkan.

\section{Pengaruh Perbandingan Bahan Baku Dan Air Terhadap Yield Etil Asetat}

Pengaruh perbandingan bahan baku dan air terhadap yield etil asetat ditunjukkan pada gambar 3 di bawah ini.

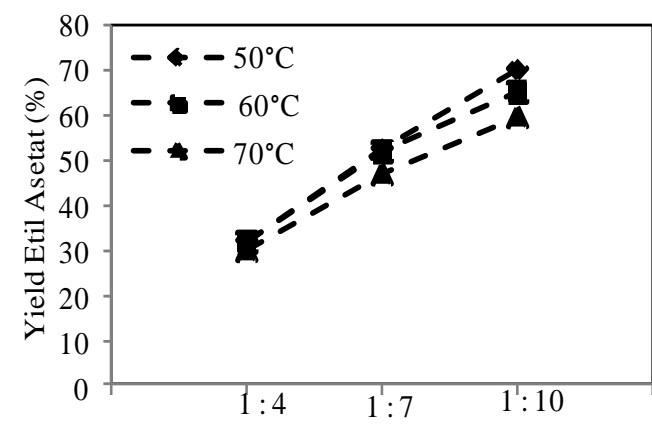

Perbandingan Bahan Baku dan Air

\section{Gambar 3. Pengaruh Perbandingan Bahan Baku dan Air Terhadap Yield Etil Asetat}

Seperti yang telah dibahas sebelumnya massa etil asetat semakin meningkat seiring dengan penurunan perbandingan bahan baku dan air. Yield etil asetat dapat diperoleh dari rumus:

Yield $=\frac{\text { massa etil asetat }}{\text { berat } \text { kulit pisang }} \times$ kemurnian

Dari persamaan 1 yield etil asetat berbanding lurus dengan massa etil asetat. Artinya semakin besar massa etil asetat maka yield etil asetat yang diperoleh juga akan semakin meningkat. Oleh karenanya, yield etil asetat akan semakin meningkat seiring dengan peningkatan rasio perbandingan bahan baku dan air.

Yield etil asetat tertinggi adalah pada kondisi perbandingan bahan baku dan air $1: 10$ dan suhu $50^{\circ} \mathrm{C}$ dengan perolehan yield sebesar $70,377 \%$. Sedangkan yield etil asetat terendah adalah 29,922 \% dengan kondisi perbandingan bahan baku dan air $1: 4$ dan suhu $70^{\circ} \mathrm{C}$. 


\section{Pengaruh Suhu Hidrolisis Terhadap Yield Etil Asetat}

Pengaruh perbandingan suhu terhadap yield etil asetat ditunjukkan pada gambar 4 berikut.

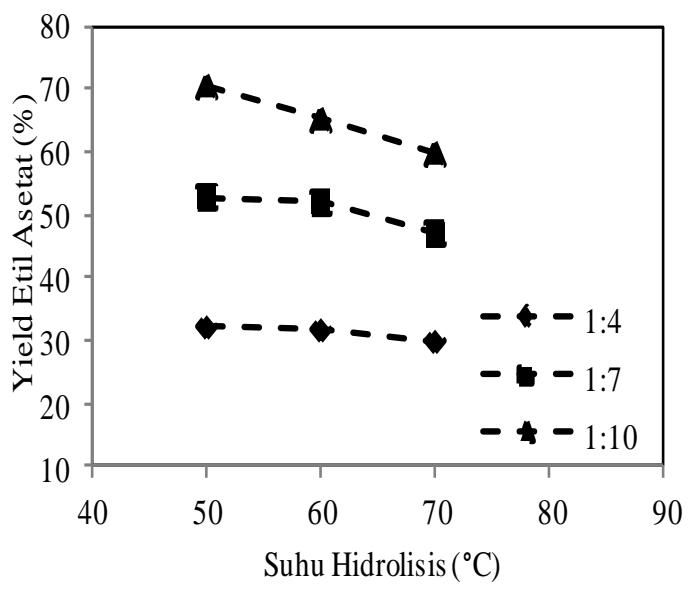

\section{Gambar 4. Pengaruh Suhu Hidrolisis Terhadap Yield Etil Asetat}

Pada gambar 4 dapat dilihat bahwa yield etil asetat cenderung menurun seiring dengan peningkatan suhu hidrolisis. Dari grafik dapat dilihat, yield etil asetat tertinggi adalah $70,377 \%$ dengan kondisi suhu $50^{\circ} \mathrm{C}$ dan perbandingan bahan baku dan air 1 : 10 . Sedangkan yield etil asetat terendah adalah $29,922 \%$ dengan kondisi suhu $70^{\circ} \mathrm{C}$ dan perbandingan bahan baku dan air $1: 4$.

Reaksi hidrolisis merupakan reaksi endotermis sehingga memerlukan panas untuk dapat bereaksi. Peningkatan suhu pada proses hidrolisis dapat mempercepat proses hidrolisis yang berperan dalam pemutusan ikatan lignin dan hemiselulosa serta meningkatkan laju hidrolisis. Tetapi, jika suhu terlalu tinggi, maka katalis $(\mathrm{HCl})$ akan menguap yang mengakibatkan melambatnya reaksi hidrolisis tersebut yang nantinya akan berpengaruh terhadap konsentrasi glukosa yang diperoleh [13, 21]. Dari grafik dapat dilihat bahwa seiring dengan peningkatan suhu, yield etil asetat semakin menurun. Hal ini dikarenakan pada suhu di atas $50{ }^{\circ} \mathrm{C}$ katalis $\mathrm{HCl}$ telah menguap yang berakibat pada rendahnya perolehan glukosa hasil hidrolisis yang berakibat pada yield etil asetat yang diperoleh.

\section{Kesimpulan}

Peningkatan rasio perbandingan bahan baku dan air pada proses hidrolisis menghasilkan etil asetat yang lebih banyak.
Pada pembuatan etil asetat dengan proses hidrolisis, fermentasi dan esterifikasi, kondisi terbaik diperoleh pada suhu hidrolisis $50^{\circ} \mathrm{C}$ dan perbadingan jumlah bahan baku dan air adalah 1:10 dengan yield sebesar $70,377 \%$.

\section{DAFTAR PUSTAKA}

[1] Arun Bahl, B.S. Bahl, A Textbook of Organic Chemistry. (New Delhi: S. Chand \& Company LTD, 2007), hal. 501

[2] Asih Sukowati, "Produksi Bioetanol Dari Kulit Pisang Melalui Hidrolisis Asam Sulfat", Tesis, Program Pasca Sarjana Magister Teknologi Industri Pertanian UNILA, Bandar Lampung, 2013. hal. 8-10

[3] Asteria Apriliani, Franky Agustinus, "Pembuatan Etanol dari Kulit Pisang Secara Fermentasi", Jurnal Teknologi Kimia dan Industri, 2(2) 2013 : hal. 177-180.

[4] Bill Owens, Craft Of Whiskey Distilling, (Hayward: White Mule Press, 2009), hal. 3-4

[5] David W. Armstrong, Stanley M. Martin, Hiroshi Yamazaki, "Production of Ethyl Acetate from Dilute Ethanol Solutions by Candida utilis", Biological and Bioengineering, XXVI (Desember, 1983), hal. 1038-1041

[6] Dwi A. Setyawardhani, Yoenitasari dan Sri Wahyuningsih, "Kinetika Reaksi Esterifikasi Asam Formiat dengan Etanol pada Variasi Suhu dan Konsentrasi Katalis", Ekulibrium. 4(2) 2005 : hal. 64-70.

[7] Dwi Andriani. "Studi Pembuatan Bolu Kukus Tepung Pisang Raja (Musa paradisiaca L.)". Skripsi, Program Sarjana. Fakultas Pertanian Universitas Hasanuddin, Makassar, 2012, hal. 5

[8] Dyah Tri Retno, Wasir Nuri, "Pembuatan Bioetanol dari Kulit Pisang", Pengembangan Seminar Nasional Teknik Kimia Pengembangan Teknologi Kimia untuk Pengolahan Sumber Daya Alam Indonesia (Februari, 2011), hal. E11-1 - 11-7

[9] Ekawati Danial, "Perbanyakan In Vitro Tanaman Pisang Ambon Kuning Dan Raja Bulu", Tesis, Program Studi Pascasarjana Fakultas Pertanian, Universitas Lampung, Bandar Lampung, 2014, hal. 2

[10] Endah, R. D., Sperisa, D., Adrian, N., Paryanto, "Pengaruh Kondisi Fermentasi terhadap Yield Etanol Pada 
Pembuatan Bioetanol Dari Pati Garut", Gema Teknik, X (Juli, 2007), hal. 83-88

[11] Endang Mastuti, Dwi A. Setyawardhani, "Pengaruh Variasi Temperatur Dan Konsentrasi Katalis Pada Kinetika Reaksi Hidrolisis Tepung Kulit Ketela Pohon", Ekuilibrium, IX (Januari, 2010), hal. 23-27

[12] Enny K. Artati, Margaretha Novia, Vissia Widhie, "Konstanta Kecepatan Reaksi Sebagai Fungsi Suhu Pada Hidrolisis Selulosa Dari Ampas Tebu Dengan Katalisator Asam Sulfat", Ekuilibrium, IX (Januari, 2010), hal. 1-4

[13] Jatmiko Wahyudi, Wusana A. Wibowo, Yulian A. Rais, Atika Kusumawardani, "Pengaruh Suhu Terhadap Kadar Glukosa Terbentuk dan Konstanta Kecepatan Reaksi pada Hidrolisa Kulit Pisang". Prosiding Seminar Nasional Teknik Kimia Pengembangan Teknologi Kimia Untuk Pengolahan Sumber Daya Alam Indonesia (Februari, 2011), hal. B09-1 - B09-5

[14] Ni Ketut Sari, "Pembuatan Bioetanol dari Rumput Gajah dengan Distilasi Batch", Jurnal Teknik Kimia Indonesia, 8(3) 2009 : hal. 94-103

[15] Riswiyanto, Kimia Organik (Jakarta: Erlangga)

[16] Shyam Kumar, Ganesh Moorthy, Rajeswari, Harikrishnan, "Utilization Of Waste Ripe Banana, And Peels For Bio Ethanol Production Using Saccharomyces Cerevisiae", Journal Of Bioscience Research, 2(2) 2011 : hal. 67-71.

[17] SNI. Etil Asetat. Pusat Standarisasi Industri. Departemen Perindustrian. 1992

[18] Sri Haryani "Produksi Bioetanol dai Sirup Glukosa Ubi Jalar (Ipomoea batatas L.) Menggunakan Saccharomyces cerevisiae". Skripsi, Program Sarjana, Fakultas Teknologi Pertanian IPB, Bogor, 2008, hal. 33

[19] Sri R. Gusmarwani, M. Sri P. Budi, Wahyudi B. Sediawan, Muslikhin H, "Pengaruh Perbandingan Berat Padatan Dan Waktu Reaksi Terhadap Gula Pereduksi Terbentuk Pada Hidrolisis Bonggol Pisang", Jurnal Teknik Kimia Indonesia, IX (Desember, 2010), hal. 77-82

[20] T. Brandberg, N. Sanandaji, L. Gustaffson, C.J Franzen, "Continuous Fermentation of Undetoxified Dilute Acid Lignocelluse Hydrolysate by
Saccharomyces cerevisiae ATC 96581 Using Cell Recirculation, Biotechnology Progress Jounal, volume 21 (2005), hal 1093-1101.

[21] Veronika Yuliani, "Sintesis Ester Laktovanilat dari Asam Vanilat dan Laktosa serta Uji Aktivitas Antioksidan", Skripsi, Program Sarjana, Fakultas Matematika dan Ilmu Pengetahuan Alam UI, Depok, 2008, hal. 21 